\title{
ROMEIROS/AS E ROMARIAS EM JUAZEIRO DO NORTE Protagonismo de uma liturgia popular Uma visão antropológica ${ }^{1}$
}

\author{
Dra. Ir. Ana Teresa Guimarães e Dra. Ir. Annette Dumoulin
}

\section{RESUMO}

Este artigo apresenta algo da riqueza de expressões religiosas, rituais, simbólicas e misticas que os romeiros inventam e reinventam nas estradas que levam até Juazeiro do Norte, CE. Procura-se entender porque essas expressões atravessam o tempo numa longa tradição que não mata a originalidade nem a criatividade dos "afilhados do Padre Cícero". É uma leitura psicológica e antropológica que pode servir de base para um aprofundamento teológicolitúrgico.

Palavras Chaves: romeiro, "espacialidade", procura, caminho, sonho, esperança, salvação.

\begin{abstract}
This article presents some of the richness of religious expression, rituals, symbolic and mystical that the pilgrims who invented and reinvented on the roads leading to North Juazeiro, CE. There has been an effort to seek to understand why that these expressions cross through time in a long tradition which does not kill the originality and the creativity of "godchildren of Father Cicero." It is a psychological and anthropological understanding, which can serve as a basis for a deeper theological-liturgical.

Keywords: pilgrim, "spatiality", search, road, dream, hope and salvation.
\end{abstract}

\footnotetext{
Este estudo, em vista da assessoria do XX Encontro da ASLI - Associação dos Liturgistas do Brasil, com o tema Romarias, piedade popular e liturgia, realizado em Cachoeira do Campo, Diocese de Mariana, MG, em 2009, se propõe a aprofundar a dimensão antropológica e psicológica das romarias de Juazeiro do Norte, buscando aí uma intersecção com a Liturgia da Igreja.
} 
Os pés dos romeiros são como lápis. Nós, pobres, somos de poucas letras, Mas a gente também escreve com os pés. Só que para ler essa escrita precisa conhecer os chãos da vida e das estradas duras. E é preciso curtir o couro dos pés. Pezinhos de pele fina não deixam quase nada escrito nos caminhos da vida ${ }^{2}$.

\section{ROMARIA: UMA ESPACIALIDADE MÍSTICA.}

O romeiro transforma, organiza e vive o espaço em dimensões religiosas, numa "espacialidade mística", uma grande liturgia.

A "espacialidade" em psicologia fenomenológica é o espaço vivido, subjetivo, em oposição ao espaço que se mede objetivamente (100 metros quadrados, por exemplo).

Há Igrejas que ajudam a rezar, outras não! Elas podem medir o mesmo espaço geométrico, mas este é "habitado" de maneira diferente. É uma questão de espacialidade.

No dia a dia, nossa casa é a espacialidade vivida como "centro" de nosso mundo. Na hora da romaria, o peregrino deixa seu centro de referência costumeiro e caminha em direção a outro centro, onde ele projeta valores, desejos, sonhos que motivam a sua peregrinação na terra. Contrariamente ao que alguns pensam, a romaria não é fuga da realidade diária, mas procura de sentidos, reabastecimento da esperança para viver melhor esta realidade.

Quais seriam os "valores" e "sonhos" projetados pelo romeiro no Centro de romaria que é Juazeiro? Esse estudo nos parece fundamental para entender a originalidade de sua liturgia, de seu ritual de aproximação do sagrado visualizado por ele nessa "terra da Mãe das Dores e do Padrinho Cícero".

Será que ele é mesmo protagonista de uma liturgia popular? Anos de observação e convivência na espacialidade romeira em Juazeiro, nos convenceram que sim. É necessário lembrar o quanto os romeiros do Padre Cícero sofreram oposição da parte do clero nordestino.

2 Depoimento de Romeiro, citado por SOARES, Sebastião Armando Gameleira. A romaria dos pobres de Deus, in Romeiros de ontem e de hoje Estudos Bíblicos, n²8, Vozes, 1990, p.33 
Para a Igreja católica, até há poucos anos, Juazeiro era visto como um Centro de "contra-valores": fanatismo, idolatria, ignorância, desobediência... Em resposta, o romeiro desenvolveu sua criatividade, originalidade e convicção numa arte de viver, de inventar e reinventar as expressões de sua fé, fortificando assim, sua capacidade de resistência e sua fidelidade ao Padrinho Cícero. A "espacialidade da romaria" ficou livre de eventual imposição ou proposição clerical, para ser geradora de comportamentos, gestos, ritos próprios.

Mas, por que houve perseguição aos romeiros, a Juazeiro e ao Padre Cícero? Não é lugar aqui para desenvolver essa longa e tumultuosa história. Lembraremos apenas alguns fatos importantes:

Em 1889, aconteceu na capelinha do lugar um "milagre eucarístico" que foi condenado pela Igreja como fenômeno vão e supersticioso (1894). A hóstia se transformou em sangue na boca da Beata Maria de Araújo. O fato foi silenciado por obediência à decisão romana, mas os romeiros continuaram a acreditar no "milagre" e a visitar o "Santo Juazeiro", Nossa Senhora das Dores e o Padrinho Cícero. Este foi condenado mais de uma vez por ser julgado o principal responsável de atrair romeiros, prolongando assim um movimento considerado fanático. ${ }^{3}$

Hoje, cerca de dois milhões de romeiros visitam anualmente a "Jerusalém Nordestina".

\section{ALGUNS VALORES E SONHOS QUE O ROMEIRO PROJETA NO "CENTRO-JUAZEIRO".}

Em síntese, podemos afirmar que:

1) O Cariri, Pe.Cícero e Juazeiro pertencem ao tesouro mítico do povo Nordestino.

3 Entre os inúmeros livros que tratam da questão de Juazeiro e do Padre Cícero, destacamos três dos últimos publicados: BARBOSA, Francisco Salatiel de Alencar: O joazeiro celeste: tempo e paisagem na devoção do Padre Cícero. São Paulo: Attar Editorial (coleção de antropologia), 2007; BARROS, Luitgarde Oliveira Cavalcanti: Juazeiro do Padre Cícero, a terra da Mãe de Deus. Fortaleza: IMEPH, $2^{\mathrm{a}}$ ed. revista e ampliada, 2008; BRAGA, Antônio Mendes da Costa: Padre Cícero, sociologia de um Padre, antropologia de um Santo. Bauru: EDUSC, 2008 
2) Juazeiro é um "centro" de salvação econômica no Nordeste.

3) Juazeiro é um "centro" de salvação religiosa.

4) Juazeiro é a concretização da salvação "Católica Romana" em terra brasileira.

5) Juazeiro é a experiência de ser "povo roceiro", "gente nordestina", "nação romeira".

\section{1) O CARIRI, PE.CíCERO E JUAZEIRO: TESOURO MÍTICO DE UM POVO QUE SE PROCURA.}

"O mito é o sonho de um povo, como o sonho é o mito do indivíduo"4 Uma cultura sem mito é uma cultura doente . O mito é uma explicação do real, é a forma primeira da elaboração do dado da experiência.

\section{1: A lenda da "pedra da Batateira".}

Segundo o cineasta e pesquisador Rosemberg Cariry, ${ }^{5}$ os remanescentes das tribos Cariris, ocupando uma grande parte do Sertão Nordestino, guardaram codificados, na sua sensibilidade, intuição e memória, a evocação da "lagoa encantada" - lugar mítico das suas origens. Para eles, todo o vale do Cariri era um mar subterrâneo. Debaixo da terra, dormia a Serpente d'Água, cujo imenso caudal era represado pela "Pedra da Batateira", ao sopé da Chapada do Araripe. Precisamente, onde hoje está situada a Matriz do Crato, erigida sob a invocação de Nossa Senhora do Belo Amor, era a cama da baleia. Os Pajés Cariris profetizavam que a "Pedra da Batateira" iria rolar e todo o vale do Cariri seria inundado. As águas, em fúria, devorariam os homens maus que tinham roubado a terra e escravizado os índios. Quando as águas baixassem, a terra voltaria a ser fértil e livre e os Cariris iam repovoar o "Paraíso" que tinham perdido. Por volta de 1779, os Cariris atribuíram esta profecia ao Frei Vital Frescarolo, missionário Capuchino. Em um momento de crise de dissolução da cultura e do sentido de "comunidade", os caboclos

4 HARVEY COX, Jane Harrison, La fête des fous, essai théologique sur les notions de fêtes et de fantaisie, Paris : Seuil, 1971, p.85.

5 CARIRY, Rosemberg. Jornal Diário do Nordeste 30/11/2008 in Caderno 3, p.10: Cariri, a nação das utopias.

12 ReVISTA de Cultura TeOlógIcA - V. 17 - N. 67 - ABR/JUN 2009 
Cariris buscaram assim, uma autoridade exterior para dar à lenda foros de verdade sagrada e manter a coesão do grupo. (...) Esse "caldo mítico" original foi propício à fecundação e eclosão dos futuros movimentos religiosos. Os "expulsos do "Paraíso" sonhavam e ainda sonham com o seu retorno.

A lenda, com o tempo passou por modificações ao sabor das necessidades históricas. Para os romeiros que chegavam a Juazeiro, a profecia da grande enchente era inquietante, pois significava que Juazeiro ia também ser inundado. Surgiu então, a "boa nova" de que o Padre Cícero amarrara a "pedra da Batateira" com grossas correntes de ferro e teria pedido a proteção da Mãe do Belo Amor. A pedra só iria rolar no final dos tempos e Juazeiro seria suspenso no céu para que as águas passassem devorando as iniquidades do mundo. Baixadas as águas, teria início a era do "Espírito Santo", e os pobres e deserdados da terra, herdariam o "paraíso".

Nas suas andanças pelo Cariri, na época em que negociava com cachaça, Antônio Conselheiro escutou de caboclos da região a lenda da "pedra da Batateira", a partir da qual fundamentaria a profecia que pregava nos sertões da Bahia: "O Sertão vai virar mar e o mar vai virar sertão"(...)

E Rosemberg conclui: "Juazeiro é um rio que flui das profundidades da alma coletiva, um mundo que se inventa a si - mesmo. Não importa que novas lendas surjam a cada dia e que antigos mitos sejam sempre recriados - tudo gira em torno do Padre Cícero. (...) É inútil buscar nas ações históricas e contraditórias do Padre Cícero homem, todas as motivações para a fé do povo. O mito do "Padim Cíço" tomou o lugar do homem concreto e histórico. (...) O "Padim Ciço" é água caririzeira que brota do mar do inconsciente coletivo e universal para desaguar e fertilizar as securas dos sertões. (...) Em Juazeiro, as pedras se transformarão em pão, ${ }^{6}$ e nos rios, correrão leite e mel. Enquanto o "Paraíso" não se desencanta e o sonho da Nova Jerusalém" não se realiza, o povo resiste e encontra, na sua própria história e cultura em construção, as formas de luta e da necessária resistência. A cultura cabocla-cariri não é uma cultura de miséria, é antes a cultura que à miséria resiste e que afirma a vida no ritual da beleza possível.(...) O povo, reprimido e massacrado em Monte Rodeador, Canudos, Juazeiro, Caldeirão,

6 Palavras do próprio Padre Cícero: "As pedras vão virar pão na serra do Catolé! " . Só depois, quando os moradores foram quebrar pedras e vendê-las e alimentar suas famílias, que entenderam a profecia do Padrinho. 
Pau de Colher... já sabe o quanto dói a repressão e sempre encontra as formas mais eficazes de proteger seus segredos e cultuar seus 'deuses'".

\section{2: Cantadores de viola e poetas de cordel8.}

A leitura da literatura do Cordel nos faz entrar no mundo mítico do homem Nordestino: um mundo repleto de estórias, lendas e símbolos que falam e ressoam profundamente na alma do sertanejo. É sua leitura preferida.

Os títulos de Cordel são sugestivos: "A Mendiga da estrada e os milagres do Padre Cícero", "Palavras do Padre Cícero sobre a guerra nuclear" (João José Silva); "O sonho do Padre Cícero na hora de sua morte" (L.R.dos Santos); "Visão milagrosa do homem que ouviu o Padre Cícero nas frentes de trabalho", "Meu sonho com Padre Cícero" (João Bandeira Caldas);" O homem que virou bicho, porque duvidou do Padre Cícero" "Verdades incontestáveis ou a voz dos Romeiros" (Uma resposta ao livro "O Apostolado do embuste); "Palavras do Padre Cícero sobre o recenseamento" (Heráclito Amorim); "Os dois jovens que andaram 122 léguas pelo poder do Padre Cícero" (Abraão Batista); "Conselhos que o Padre Cícero dá aos sertanejos" (Zilmar Barbosa de Santos), "Padre Cícero e a ecologia" (Willian Brito), "Nascimento de Padrinho Cícero e a troca misteriosa das crianças" (João do Cristo Rei) "O homem que falou com o diabo em Juazeiro" (João do Cristo Rei) etc.

A título de exemplo, vejam a beleza do Cordel de Patativa do Assaré: (Saudação ao Juazeiro do Norte):
Mesmo sem eu ter estudo sem ter do colégio o bafejo, Juazeiro, eu te saúdo com o meu verso sertanejo Cidade de grande sorte,

7 CARIRY, Rosemberg, op.cit. p. 10.

8 Para mais informações sobre essa literatura de folhetos nordestinos, ler, de Gilmar de Carvalho: Lyra popular: o cordel do Juazeiro Museu do Ceará, 2006 (disponível na internet) STINGHEN, Marcela Guasque: Padre Cícero: a canonização popular. Tese de Mestrado da UNICAMP, Campinas, 2000 (disponível na internet) A autora estuda cerca de 160 folhetos nordestinos sobre o Padre Cícero. 
de Juazeiro do Norte

tens a denominação,

mas teu nome verdadeiro

será sempre Juazeiro

do Padre Cícero Romão.

O Padre Cícero Romão

que, vocação celeste

foi, com direito e razão

o Apóstolo do Nordeste.

Foi ele o teu protetor

trabalhou com grande amor,

lutando sempre de pé

quando vigário daqui,

ele semeou em ti

a sementeira da fé.

E com milagre estupendo

a sementeira nasceu,

foi crescendo, foi crescendo

Muito ao longe se estendeu

com a virtude regada

foi mais tarde transformada

em árvore frondosa e rica.

E com luz medianeira

inda hoje a sementeira

cresce, flora e frutifica.

Juazeiro, Juazeiro

jamais a adversidade

extinguirá o luzeiro

da tua comunidade.

morreu o teu protetor,

porém a crença e o amor

vive em cada coração

e é com razão que me expresso

tu deves o teu progresso

ao Padre Cícero Romão 
Aquele ministro amado que tanto favor nos fez, conselheiro consagrado e o doutor do camponês. contradizer não podemos $\mathrm{E}$ jamais descobriremos O prodígio que ele tinha: Segundo a popular crença, curava qualquer doença, com malva branca e jarrinha.

Juazeiro, Juazeiro tua vida e tua história para o teu povo romeiro merece um padrão de glória. De alegria tu palpitas, ao receber as visitas de longe, de muito além, Grande glória tu viveste! Do nosso caro Nordeste tu és a Jerusalém.

Sempre me lembro e relembro, não hei de me deslembrar: O dia 2 de Novembro, tua festa espetacular pois vem de muitos Estados os carros superlotados conduzindo os passageiros

e jamais será feliz aquele que contradiz a devoção dos romeiros.

No lugar onde se achar um fervoroso romeiro, ai daquele que falar, contra ou mal, do Juazeiro. 
Pois entre os devotos crentes, velhos, moços e inocentes, a piedade é comum, porque o santo reverendo se encontra ainda vivendo no peito de cada um.

Tu, Juazeiro, és o abrigo da devoção e da piedade. Eu te louvo e te bendigo por tua felicidade, me sinto bem, quando vejo que tu és do sertanejo a cidade predileta.

Por tudo quanto tu tens recebe estes parabéns do coração de um poeta.

Um outro cordel, bem diferente do primeiro, mas também revelador:

"O Homem que virou bicho, porque duvidou do Padre Cícero" (autor desconhecido)

Quem já foi ao Juazeiro

Do Padre Cícero Romão

Se lembra que ele disse

Toda noite em seu sermão

Que Deus é pai poderoso

E olha o mentiroso

Com olhar de maldição.

O mentiroso é capaz

De tudo quanto é ruim

Dizer que Deus não é Deus

Dizer que santo é Caim

Difamar a mãe e patroa

Caluniar gente boa

O mentiroso é assim. 
Um homem mentia muito

Depois foi se confessar

Contou tudo a meu padrinho

Que não podia negar,

Devido as mentiras dele

O que o padre disse a ele

Eu aqui quero contar.

Meu padrinho lhe disse, filho

Todo homem mentiroso

É mau pai, é mau amigo

É mau filho. É mau esposo

É tipo sem coração

Que não merece perdão

Do grande Deus poderoso.

O mentiroso é um Judas

Que vendeu o Salvador

O mentiroso é infame

É um caluniador

Que joga as faltas que tem

Em um cidadão de bem

Para manchar seu valor.

Mentiroso é viciado

A mentir todo segundo

É ladrão da consciência

É covarde, vagabundo

Quem mente é filho do diabo,

Cria chifre, e cria rabo

Sai dando popa no mundo.

O mentiroso é o anjo

Que Deus tirou do caderno

Por ele querer tomar

O trono de Deus Eterno

Devido a audácia dele 
Nosso Pai expulsou ele

As profundas do inferno.

Não há quem conte os defeitos

Que o mentiroso tem

Todo seu intento é

Manchar os homens de bem

No fim as misérias dele

Só ofendem mesmo a ele

Não prejudicam a ninguém.

O mentiroso é sujeito

A rinchar como cavalo

A latir como cachorro

Cantar remendando galo

A miar como raposa

É sujeito a tanta cousa

Meu filho, que eu nem falo.

É sujeito a correr bicho

Sete anos sem parar

Cresce os dentes mas não morde

Cria asas sem voar

Mas isto tudo é pouco

Cria depois um catoco

No canto de se sentar.

Também pode transformar-se

Ou num porco, ou num jumento

Numa cobra, num papa-vento

Em lama, em monte de lixo

Ou em outro qualquer bicho

Num leproso feio e nojento.

Quem mente hoje é condenado

De Jesus e de Maria

De Deus Pai onipotente 
Da sagrada eucaristia É terra, é poeira, é lixo Tem que virar-se no bicho Que o Padre Cícero dizia.

O homem ouvia calado Aquele santo sermão Mas tinha Cristo na boca E o diabo no coração Devido aquele capricho Terminou correndo bicho Sete anos no sertão.

Um terceiro cordel, bem antigo (1936) teve bastante influência sobre o Romeiro.

Severino Pinto: "O Padre Cícero: foi visto de novo no Juazeiro, por um romeiro, no dia 15 de Maio de 1936, às 10 horas da noite na Igreja do Horto".

A mim contou um romeiro

O qual todo ano ia

Visitar o Juazeiro

Fazer sua romaria

Era uma obrigação

Que todo ano fazia.

Mas depois que faleceu

O Padre Cícero Romão

Não foi mais a Juazeiro

Acabou a devoção

Sonhou, dizendo: Vai

Cumprir tua obrigação!

Acorda impressionado

Já o dia amanhecido,

A mulher lhe perguntou:

$\mathrm{O}$ que tens, meu marido?

Ele contou a miúdo

O sonho que tinha tido. 
Oh! Minha velha, eu passei

A noite em um desespero,

Sonhando, ouvindo uma voz,

Clamando sem paradeiro

Dizendo: Porque deixastes

De visitar Juazeiro?

Eu em sonho respondia

Porque meu Padrinho morreu!

Te enganas: disse a voz

Pois ele não faleceu;

Fez somente uma viagem

Aonde não digo eu.

Se pensares que é certo

Que o Padre Cícero é morto,

Vai a noite que verás

Ele passear no Horto

Abençoando seus filhos

Dando aos romeiros conforto.

Me disse o romeiro que

Se preparou e seguiu

Com quinze dias chegou

A noite, andando viu

Um vulto da forma que

O sonho lhe traduziu.

Ele parando, olhou,

Passeava um ancião

Vestido em uma batina,

Escorado em um bastão,

Era a copia fiel

Do Padre Cícero Romão.

Meu Padrinho? Pronto, filho!

Virou-se e disse ao romeiro: 
Todo aquele que quiser, Da minha benção ser herdeiro, Não deixe de todo ano, Visitar o Juazeiro.

O romeiro que contou O sonho que tinha tido Ele disse: Eu Ihe avisei Porque estavas esquecido, Se não te aviso, não sabes Quanto tu tinhas perdido.

Vá a missa, se confesse, Preze a religião. Jogo, dança, bebedeira, Vaidade e corrupção, Tudo quanto for mundano A nada dê atenção.

Não faltará a você Sempre meu bendito abono Velando por quem for meu Não sinto sede nem sono Em quarenta, o Juazeiro Volta seu legitimo dono.

$\mathrm{O}$ romeiro disse que Perguntou a ele assim: Motivo de tanta guerra Corrupção, tempo ruim Ele disse: são as coisas Que já estão perto do fim.

Adeus, meu filho que vou A minha missão cumprir Não tenho substituto Eu mesmo tenho que ir. 
Se ainda queres me ver

Eu amanhã torno a vir.

Aleluia, pois conosco

Disse aquilo e ausentou-se

$O$ romeiro estava olhando

Não viu onde encantou-se

Sabe que no mesmo instante

Da vista dele ocultou-se.

Voltou pra onde estava

Hospedado agasalhou-se

As oito horas da noite

Armou a rede e deitou-se

Sem dizer nada a ninguém

De tudo quanto passou-se.

Passou o dia andando

Pelas ruas da Cidade

Não quis contar o que viu

Temendo alguma maldade

Podia algum protestante

Querer zombar da verdade.

A noite tornou a ir

Chegou no mesmo lugar

Avistou o mesmo vulto

Ele torna a perguntar:

É meu Padrinho? É, filho

Pode se aproximar.

Meu padrinho, posso plantar?

Lhe perguntou o matuto.

Pode, mas procure terra

Que dê saboroso fruto.

Quem planta boa semente

Só pode ter bom produto. 
Foi feliz, voltou em paz, Contou o romeiro a mim.

Todos que forem romeiros

$E$ não fizeram assim

Faz pena a pessoa ver

De qual forma é o seu fim.

Ir a missa é um dever

Confessar-se ainda é mais,

Uma confissão contrita

Todo pecador que faz

Se aproxima de Deus

Se ausenta de Satanás.

Disse mais que todo dia

Fazia uma petição

A Deus, para ver se Ele

Tinha a santa compaixão

Do povo que está todo

No caminho da perdição.

A corrupção aumentou

Minguou a honestidade.

A mentira triunfou

Submergiu-se a verdade

O escândalo tomou conta

Do trono da vaidade.

Dança, jogo, bebedeira

Presunção e egoísmo

Catimbó e bruxaria

O mentiroso espiritismo

Vive tudo arrastando

O povo para o abismo.

Corra como já lhe disse

De jogo, bebida e dança

24 Revista de Cultura TeOlógica - v. 17 - N. 67 - ABR/JUN 2009 
Vá nos domingos a Igreja

Ouça com perseverança

De Deus as santas palavras

Que tens o céu por herança.

Jesus pela Palestina

Mostrou somente os sinais

Dizendo com gente ingrata

Oh! Mundo tu ficarás

Adeus! Até mil e tanto

$A$ dois mil não chegarás.

Disse mais na Galiléia

Em um bendito sermão

Tudo foge, tudo passa

Tudo tem consumação

Passa o céu e passa a terra

Mas minha palavra, não.

Foi a recomendação

Que o Padre fez ao romeiro

Quem pensar que é mentira

Encha o bolso de dinheiro

Se disponha a viajar

Vá até o Juazeiro.

A noite ande no Horto

Crave em Deus o pensamento

O Padre Cícero, visível

Virá no mesmo momento

Isto é, bem entendido

Se tiver merecimento. 


\section{3: Os "benditos-salmos" de romeiros.}

Centenas de "benditos"9 são outra fonte de pesquisa para quem quer aprender a linguagem dos romeiros. Há benditos para todos os momentos de sua Liturgia: bendito da saída de casa, benditos em favor do motorista, do organizador da romaria, benditos da viagem, da chegada a Juazeiro, da subida ao Horto, da visita ao túmulo do Padre Cícero, bendito da despedida e volta para a casa etc.

Um dos benditos que define melhor a vocação do romeiro é certamente aquele onde ele mesmo reconhece que foi Nossa Senhora que o chamou. Ele tem absoluta certeza que, sem este chamado, a romaria não acontece. Quando a Mãe chama, tudo se torna possível. E o romeiro canta assim:

Nossa Senhora me chama, eu quero the responder. Mostrai, minha Mãe das Dores, o que eu devo fazer. Fazei, ó Romeiros meus, o que Jesus vos disser, Ele é a vida e o caminho, quem o segue não vai se perder.

Uma mesma confiança é cantada no Bendito das Candeias:

Bendita e louvada seja a luz que mais "alumeia".

Valei-me, meu Padrinho Cícero e a Mãe de Deus das Candeias. O que caminho tão longo, cheio de pedra e areia, percorre o bom peregrino da Mãe de Deus das Candeias.

No caminho de Juazeiro, nunca ninguém se perdeu por causa da "luminura" da Mãe de Deus das Candeias.

E na hora de começar a viagem, um bendito cheio de determinação!:

Tirei a chave da porta, botei os pés no caminho

Pra visitar Juazeiro, pedir bênção a meu Padrinho.

Para o Romeiro, Juazeiro é um mistério, uma cidade encantada. Neste bendito, ele afirma:

Bendito e louvado seja /o Santo nome de Jesus!

\footnotetext{
${ }^{9}$ Benditos: cantos repetitivos numa melodia lenta e típica que fazem parte do repertório e da criatividade dos romeiros do padre Cícero e da Mãe das Dores. Cada ano, os benditos antigos são retomados, ensinados aos mais jovens, mas sempre há novos benditos com letra apropriada aos acontecimentos atuais. A exemplo, a morte do Padre Murilo, o título de Basílica dado a Igreja Matriz das Dores...
} 
Pra salvar os pecadores/ morreu pregado na Cruz. O Reino de Juazeiro/ Deus Pai eterno entregou Jesus entregou a chave,/ Padrinho Ciço destrancou. Juazeiro é encantado,/ Padrinho Cícero a nós dizia O mistério que tem nele/ só a Mãe de Deus sabia. O nome de Juazeiro/ foi meu Padrinho que botou. Escrita em letra de ouro,/nunca mais se acabou..

Um "bendito-salmo" de chegada muito antigo, lembra a vocação do romeiro, parecida com a de Abraão, deixando tudo em vista da Terra prometida:

Eu deixei Pai e deixei Mãe, deixei todos meus irmãos.

Vim buscar o Juazeiro para alcançar o perdão.

E há tanto tempo que eu ando atrás do meu Senhor.

Hoje, foi que eu dei com Ele: é meu Pai, meu Salvador.!

Saia de madrugada, no pino de meio dia

Só pra ver se alcançava o coração de Maria!

Tinha fome e não comia, tinha sede e não bebia!

Só pra ver se alcançava o Coração de Maria!

A bênção, meu Pai, a bênção, me bote a sua bênção

Que eu já venho de muito longe para alcançar o perdão.

Há tanto tempo que eu ando, atrás de minha Mãe das Dores

Hoje foi que eu dei com ela, no altar cheio de flores.

A criatividade do Romeiro coloca Padre Cícero frente a Satanás! E quem ganhou a batalha?

Viva meu Padrinho Cíço!/ A ele eu quero pedir

Pra falar do seu saber/ que o pessoal quer ouvir.

Meu Padrinho quando nasceul trouxe um dom da natureza

Os milagres que fazia/ é um Santo com certeza.

Meu Padrinho foi um Padre/ respeitado no Brasil

Nunca encontrou sabido/ pra com ele discutir.

Somente o Satanás/ um dia teve ousadia

De perguntar a meu Padrinho/quantas línguas ele sabia.

Meu Padrinho sorriu e disse:/ Vou explicar neste instante.

A primeira língua é essa: Pai, Filho, Espírito Santo.

O Satanás a cavalo/ virou a rede e saiu

Não olhou nem para trás,/ num segundo se sumiu.

Meu Padrinho disse: atrevido!/ Vem comigo protestar 
Que eu quero explicar as línguas/ que eu aprendi a falar.

Morreu com noventa anos/ 3 meses e 26 dias

Tá escrito na doutrina/ que ninguém disso sabia.

Ofereço este bendito/ a meu Padrinho mensageiro

Só ele e Nossa Senhora/ são donos do Juazeiro.

Alguns desses benditos e muitos outros são cantados durante a celebração eucarística, com certa adaptação, o que favorece de maneira impressionante a participação alegre e ativa dessa imensa "nação romeira".

\section{4: Padre Cícero e o inconsciente do romeiro.}

O romeiro sonha frequentemente com o Padre Cícero! Para ele, é como se o Padrinho estivesse aparecendo em pessoa na sua vida. Ele mora no inconsciente do povo e representa sempre o lado seguro, justo, conselheiro, salvador nos momentos de angústia, de perigo. São sonhos que acontecem por exemplo, na véspera de uma cirurgia, Padre Cícero acalmando a tensão do doente. Outra vez, é o Padre Cícero aconselhando a tomar tal remédio natural, a desistir de uma viagem, ou, pelo contrário, a deixar tudo para ir morar no Juazeiro.

\section{2) JUAZEIRO: CENTRO DE SALVAÇÃO ECONÔMICA NO NORDESTE.}

No meio do Sertão árido e intolerante, o Vale do Cariri é um oásis com suas 307 fontes de água cristalina. Esta realidade não é apenas guardada na memória mítica de um povo. Ela dinamiza esperanças, certezas e realizações..$^{10}$ Os romeiros lembram frequentemente as palavras do Padrinho: "Vocês podem percorrer o mundo inteiro, como uma mãe de família com seu filho, sem encontrar uma colher de farinha para alimentá-lo: venham ao Juazeiro e aqui encontrarão. Vocês podem percorrer o mundo inteiro, as águas do mundo tendo secado, procurando e não encontrando um copo de água para beber: venham ao Juazeiro e aqui encontrarão."

\footnotetext{
10 Infelizmente, o Cariri, como todo o nosso planeta, grita por "socorro". Ler o cordel: Salve o Soldadinho-do-Araripe, de Willian Brito, disponível na Internet. Brito fala do "Jardim do Éden, nosso Cariri".
} 
O estilo é parabólico: na raiz percebemos um convite, uma injunção: "Nordestino! Não migre para o Sul! A terra que Deus Ihe deu é o Nordeste, o Cariri, Juazeiro!".

Até hoje, centenas de romeiros deixam suas terras para procurar abrigo e emprego no Juazeiro. Conversamos com diversos juazeirenses que, voltando de uma triste experiência em São Paulo, nos confiam: "Eu não vou mais não! Eu não deveria ter ido! Aqui, a gente sofre, mas come! Aqui, é uma terra de Salvação. Padre Cícero dizia que aquele que quer morar em Juazeiro deve trazer muita paciência e não ouro, porque aqui é uma terra de salvação."! Não é por acaso que o romeiro canta com tanta convicção este bendito:

Mãe das Dores, abençoai vossos filhos peregrinos

O Nordeste é a terra prometida ao Nordestino!

Mãe das Dores, protegei os irmãos Nordestinos

Que deixaram sua terra procurando outro destino.

Nosso Pai nos deu a terra pra vivermos como irmãos

Mas depois, veio o pecado e trouxe tanta divisão.

O irmão mata o irmão por um pedaço de chão

A justiça vai morrendo em todo nosso sertão.

Somos uma só família, filhos de Nossa Senhora

Vamos conquistar a terra prometida que é nossa.

Vamos conquistar a terra na justiça e no amo.r

Viveremos mais unidos pra que cesse tanta dor.

Pra que nunca mais nos deixe um irmão Nordestino

Que por falta de justiça procurou outro destino.

Ofereço este bendito a toda Corte Celeste

E a meu Padrinho Ciço, Patriarca do Nordeste.

Partilhamos o pensamento de António Braga que escreve: "Quando o sertanejo pobre ia para Juazeiro, fugindo da fome, injustiça e sofrimento, ele não era "retirante" porque neste caso a viagem ganhava um destino e um sentido religioso: o Juazeiro sagrado do Padre Cícero". ${ }^{11}$

Este valor é próprio ao espaço sagrado de Juazeiro; ele não se encontra em Aparecida do Norte, Canindé, Lourdes ou Fátima, onde o romeiro faz sua

11 BRAGA, António Mendes da Costa: Padre Cícero, sociologia de um Padre, antroplogia de um Santo Bauru: EDUSC 2008, p. 243 
visita sem pretender nem desejar morar nestes centros de Romaria. Isso faz de Juazeiro uma cidade diferente: a cidade do Padrinho Cícero e de seus afilhados que vivem à sombra da Mãe das Dores; para muitos, Juazeiro é o maior "milagre" do Patriarca do Nordeste. Eles sentem prazer em colaborar para o seu desenvolvimento. ${ }^{12}$

Esta esperança de salvação econômica inclui também a recuperação da saúde, a compra de uma casa, o abandono do vício da cachaça e até a vitória nas eleições! Como em outros centros de romaria, as salas de exvotos são espaços da "canonização do santo" pelo povo! Provas de diversas graças alcançadas pela intercessão dos santos.

Juazeiro é, para o imaginário romeiro, a prova de que, quando se juntam "trabalho e Fé", seguindo o conselho do Padrinho, pode se esperar e alcançar desenvolvimento e progresso.

$\mathrm{Na}$ sua tese de doutorado, ${ }^{13}$ Maria de Lourdes de Araújo analisa com muita acuidade os diversos "espaços" encontrados na cidade de Juazeiro. Referindo-se à pedagogia e aos ensinamentos do Padre Cícero, ela constata que "a articulação entre 'espaço sagrado' e 'espaço econômico', trabalho e Fé, emerge da própria ação do Padre Cícero, que ensinava o povo a fazer de sua casa um oratório e uma oficina. "Objetivando a superação dos problemas, ele aconselhava os indivíduos a orar e trabalhar, moldando-lhes práticas devocionais e econômicas. Dos aconselhamentos do Padre Cícero, baseados em princípios teológicos e filosóficos, consolida-se uma concepção de desenvolvimento, pautado na utopia da prosperidade. A referida utopia difundiu-se pelo Nordeste e contribuiu para a formação do "Santo" Padre Cícero no imaginário dos devotos. Simultaneamente, a utopia da promissão

12 Mas há diversos tipos de "romeiros"?, perguntamos a Seu Manoel, morador do Caminho do Horto: "O Senhor é romeiro?" Respondeu: "Eu não sei, viu?! Que Padrinho Cícero dizia que aqui tinha 3 partes de romeiros: 'Tinha os romeiros dele, tinha os romeiros de Nossa Senhora das Dores e tinha os romeiros do pirão'. Então, às vezes, eu fico pensando: 'Eu não quero ser romeiro do pirão, não!' Meu Padrinho, daí deu o significado: 'Os Romeiros da Mãe de Deus, os Romeiros meus, onde há uma inquisição contra mim,ele diz: Vamos acudir Padrinho Cícero, porque ele está sofrendo perseguição.' O outro, romeiro do pirão, diz: 'Eu?Eu vou lá, não, vou levar pau!". Esses são romeiros do medo. Oi, o do pirão, quando há um ano de seca, diz: 'Eu aqui, não fico não, sei que morro de fome, eu vou-me embora pro Sul de Alagoas, pro Maranhão, vou ver se escapo por lá!"

13 ARAUJO, Maria de Lourdes de. A Cidade de Juazeiro: trabalho e Fé 2005, Tese de doutorado pela Universidade Federal do Rio de Janeiro (disponível na internet) 
contribuiu para a formação e expansão econômicas da Cidade de Juazeiro, assegurando a memória do Padre Cícero, enquanto construção social." ${ }^{14}$

Um velho morador de Juazeiro nos dizia, pouco antes de morrer: "Eu ia trabalhar na roça como se eu fosse rezar uma missa"! Fé e trabalho: os dois lados da mesma medalha.

\section{3) CENTRO DE SALVAÇÃO RELIGIOSA, ESPIRITUAL.}

Como já constatamos, essa segunda salvação para o romeiro está intimamente ligada à primeira. A tradição oral conserva vivos os convites do Padre Cícero a todo pecador à procura de conversão. "Aqui tem sido um refúgio dos náufragos da vida - escrevia o Padre Cícero - Tem gente de toda parte que modestamente vem abrigar-se debaixo da proteção da Santíssima Virgem". Essa acolhida incondicional a todo pecador arrependido custou ao Padre Cícero a fama de proteger criminosos e cangaceiros. Os romeiros cantam os conselhos do Padrinho:

Quem matou, não mate mais, quem roubou não roube mais.

Romeiros de verdade vivem na fraternidade.

Jesus Cristo no Calvário a Deus Pai se entregou.

Vencendo a maldade, seu amor ele provou.

No exemplo de Maria, que a todos perdoou

Da morte de seu filho, ela nunca se vingou.

Combater a injustiça é o dever do Cristão.

Não é a violência que resolve a questão.

A fraqueza do pequeno é viver na solidão.

Unidos, somos fortes, no amor e no perdão.

Viver a fraternidade é como água no Sertão.

Fecunda a semente do amor no coração.

Ao chegar no Juazeiro tomei a resolução

De seguir os conselhos do Padre Ciço Romão.

Ofereço este bendito a meu Padrinho Conselheiro,

Deu a palavra certa pra sair do cativeiro.

14 IDEM. p.19 
Assim como Noé, construindo a Arca, chamava o povo à conversão, Padre Cícero é comparado à machadinha de Noé, que, com o barulho do corte da madeira, repete a quem quiser ouvir: "Te arrepende, pecador! Que nosso velho mundo já está no fim... não é de hoje que eu aviso"! ${ }^{15}$

Em 1923, o poeta de Cordel escrevia:

Assim como Noé/Gastou na barca cem anos,

Como diz a profecia/ Para salvar os humanos,

Muitos não acreditavam/E de Noé criticavam

Viviam cheios de enganos.

Uns dizem que padre Cícero/É um segundo Noé,

Eu por nada conheci/ Não vou dizer que não é

Diz outro: é um mensageiro/Que veio para o Juazeiro

Mandado pela Santa Sé. ${ }^{16}$

Hoje ainda, a comunidade dos penitentes "Ave de Jesus", em nome do Padre Cícero, percorrem as ruas de Juazeiro, pedindo esmolas e chamando o povo à conversão, seguindo os ensinamentos da "Missão abreviada"17. Coincidência? O anúncio do dilúvio já presente no mito das origens do povoCariri, volta na superfície do discurso do Padre Cícero e dos penitentes, usando dessa vez, as imagens bíblicas do Antigo Testamento. Em muitas

15 O texto mais completo é: "Meu Padrinho Cícero disse ainda: Quando Deus quis, acabou o primeiro mundo de gente, pertencente aos filhos de Adão, abençoou a machadinha de Noé. E quando Noé batia nos paus, o machado dizia: "Te arrepende, pecador!' Mesmo assim eu digo:'Te arrepende, pecador! Te arrepende, pecador! Te arrepende, pecador! Te arrepende, pecador". Que o nosso velho mundo já está no fim e já está perto de se acabar, que eu, não é de hoje que aviso. Repare as inundações que têm acontecido, os terremotos, as guerras aqui, ali e acolá, e as secas e a fome, e as doenças, as epidemias que estão marcadas para acontecer. Tudo isto está acontecendo. Só falta o dia chegar": CAMPINA, Maria da Conceição Lopes. Voz do Padre Cícero. São Paulo: Paulinas, 1985. p. 183, nº179.

16 ELIAS, Romano. A Convivência do Joazeiro e a Formalidade do Padre Cícero. Guarabira: Tip. Liv. Pedro Batista, 1923, p. 11-12.

17 COUTO, Padre Manuel José Gonçalves: "Missão abreviada" Porto: Sebastião José Pereira, 1859 
casas dos moradores do Caminho do Horto, uma pintura da Arca de Noé é pregada na "sala dos Santos". ${ }^{18}$

A espacialidade mística de Juazeiro é profundamente bíblica. Um Romeiro nos explicava o porquê de tal multidão de peregrinos em Juazeiro:

É a Fé da pessoa que se lembra de seus antepassados porque antigamente, havia alguns homens que eram conselheiros e a gente fica com a lembrança desses velhos do Antigo Testamento, de Abraão, Isaac, Jacó, Tobias, que eram homens de valor, davam conselhos e opiniões aos que queriam seguir o bom caminho...

O "Santo-Juazeiro" é um espaço onde a memória coletiva dos romeiros materializa suas crenças, sua fé: o Rio Jordão, o Horto das Oliveiras, o Santo Sepulcro são os espaços sagrados de visitação e penitência. Juazeiro é a Jerusalém Nordestina, a Cidade Santa onde o sangue de Jesus foi derramado.

\section{4) JUAZEIRO É O CENTRO DE UMA SALVAÇÃO "CATÓLICA, APOSTÓLICA, ROMANA", EM TERRA BRASILEIRA.}

Para o romeiro, Padre Cícero é o primeiro Santo Brasileiro e será sempre o maior! Madre Paulina, Frei Galvão e futuros canonizados serão bem-vindos, mas não se comparam à santidade do Padrinho!

- "Padre Cícero viveu em nossa terra, viveu as mesmas coisas que nós vivemos aqui, sofreu conosco, não é?"

- "Quando Jesus andou na terra, o Brasil ainda não tinha sido descoberto! Jesus não falava nossa língua, então Ele enviou o Pe. Cícero para exercer as suas funções...!"

-"Conheci Padre Cícero em carne humana. Para mim, penso que meu Padrinho Cícero é um santo desconhecido no meio de nós... Santo Brasileiro, não conheço. Conheço somente Santos estrangeiros..."

18 Primeira sala da casa, pequeno oratório. Uma das paredes desta sala é repleta de imagens dos santos cultuados pela família. A cada ano, geralmente na data do casamento dos donos, se celebra a "renovação da consagração da família ao Sagrado Coração de Jesus e de Maria", segundo as orientações do Padre Cícero. 
- "Padre Cícero era como a lâmpada e Deus a energia: quando Padre Cícero agia, parecia que era Deus mesmo que agia nele! Ele era como a roupa e Deus o corpo!"

A Igreja Católica Brasileira quis apropriar-se do Padre Cícero e o canonizou. O romeiro, em geral, não aprovou. Ele quer continuar pertencendo à Igreja Católica Apostólica de Roma, segundo as orientações do Padre Cícero.

Hoje, algumas Igrejas evangélicas nascem nos bairros da periferia de Juazeiro. Outras chegam na época das romarias para transformar, com muita coragem e determinação, o que eles chamam de "o Caldeirão da idolatria" em uma cidade de crentes. A organização do "impacto evangelístico" é muito bem pensada, e as diversas denominações evangélicas, vindas de todo o Brasil, se unem numa só voz para anunciar aos romeiros que "só Jesus salva"! É uma verdadeira "invasão" dos espaços sagrados e nem sempre os romeiros conseguem identificar a que Igreja pertencem esses pastores e missionários. Será que é um novo tipo de perseguição ao romeiro do Padre Cícero?

A Igreja Católica é vista apenas como aproveitadora da ignorância popular, procurando arrecadar dinheiro, alimentando as crenças no Padre Cícero.

\section{5) JUAZEIRO: EXPERIÊNCIA DE SER "POVO ROCEIRO", "GENTE NORDESTINA DE VALOR”, "NAÇÃO ROMEIRA"!}

Dois objetos-símbolos identificam o romeiro em Juazeiro: O Rosário no pescoço e o chapéu de palha na cabeça..

O rosário é a "arma que Padre Cícero nos deixou"! Num cordel muito conhecido pelos romeiros, João do Cristo Rei conta: ${ }^{19}$

19 João do Cristo Rei conheceu o Padre Cícero e é considerado pelos estudiosos como o "profeta de Juazeiro". Na publicação de seu primeiro cordel, ele escreve: "...eu vim a Juazeiro, onde encontrei uma novidade, lá, onde eu estava arranchado me contaram uma novidade de um caso que estava se dando de uma moça contando história de outro mundo...Eu achei interessante, eu digo, eu entendi de fazer um versinho, então tirei de minha mentalidade umas rimas. Fiz um versinho. Um tanto errado e coisa e tal, mas que saiu de gosto. Cheguei aqui, fui ler pro meu Padrinho Ciço, ele achou muito bonito e disse:

- Você de ora em diante vai ser poeta. Vai ser poeta.

- Meu Padrinho, eu não tenho nada o que escrever porque sou um tanto ignorante e não tenho assunto nenhum. O Sr. me dê aí um assunto..

- Faça o que você quiser e fizer, que tudo quanto você quiser e fizer eu dou por bem-feito. 
"Um rapaz foi uma noite a meu Padrinho dizer:

Peço que o Senhor me dê uma arma boa e forte

Pra onça não me morder.

Ele pegou o Rosário e lhe disse: amigo, tome!

Reze este que no mundo desastre não lhe consome

Nem cangaceiro the ofende, nem bicho feroz the come.

Quando ele seguiu viagem, que chegou no Tabuleiro

Encontrou outro rapaz seguindo o mesmo roteiro.

Então trocou seu Rosário na faca do companheiro.

Adiante numa travessa, a onça deu na batida.

Dos dois rapazes romeiros, o do Rosário escapou.

O da faca perdeu a vida."

O rosário no pescoço foi durante muito tempo, "sinal de perseguição", pois o romeiro suspendia nele uma medalha do Padre Cícero. Por isso, não podia se confessar, comungar nem receber os últimos sacramentos, sem antes arrancar o rosário e pisar em cima da medalha!

O Chapéu de palha é outro símbolo muito sugestivo: "Meu pai sempre me diz: quem não tem chapéu de palha não é reconhecido como romeiro", afirma uma jovem entrevistada. Na "despedida do romeiro" que a imprensa costuma chamar de "missa do chapéu", apesar das reclamações do Vigário, pode-se observar a "sacralização" deste sinal humilde do homem do campo. Na Missa, no momento das oferendas, o romeiro utiliza seu chapéu colocando-o em forma de cuia, num gesto de oferta a Deus.

Acompanhamos o Romeiro na sua ambulação litúrgica. Apresentaremos aqui alguns de seus gestos, ritos e orações. ${ }^{20}$

\subsection{ROMARIA: RITOS PREPARATÓRIOS.}

A romaria é um ritual de passagem e necessita de uma iniciação. "Sou romeiro desde que eu era embrião", nos confiava um jovem, filho e neto de

Pronto, daí por diante eu comecei a escrever. Deixei aquela vida do pesado e foi o tempo que me casei também, em 1931, e fui construir família com essa profissão. Meus filhos foram educados aqui em Juazeiro, no colégio... Até o momento ainda estou vivendo disto."

20 É claro que nem todos os romeiros vivem sua romaria com essas práticas. Elas são mais frequentes nos grupos de romeiros que viajam de caminhão. 
romeiros. "Um romeiro que nunca veio a Juazeiro, a gente tem obrigação de orientar. A gente só pode explicar na hora, ele vendo", dizia um "fretante", responsável de um grupo de romeiros. E a iniciação tem que ser gradativa, progressiva, e começar logo no início.

Há romeiros que inventam jeitos bonitos para economizar seu dinheirinho em vista da viagem: "Na minha roça, tenho um pedaço que é de minha Mãe das Dores. Tudo que eu recolho neste pedaço é para pagar a minha passagem e distribuir aos pedintes no Juazeiro..."

Há também uma preparação espiritual: "Quando minha viagem foi marcada para vir ao Juazeiro, meu pai disse que, durante aquele tempo que faltava, não era para fazer nada de errado, nem chamar nome, porque a gente vinha para um lugar santo".

Uma atenção especial é dada ao responsável (fretante) daquela romaria: é preciso rezar por ele e com ele: "Antes de sair em romaria, a gente reza o terço na casa do fretante... O importante é o dono do carro se preparar."

Um gesto compassivo é previsto para aqueles que não podem acompanhar: "Antes de viajar para o Juazeiro, fazemos uma procissão no bairro, para os romeiros que não podem nos acompanhar. Eles ficam tão tristes, mas a gente promete rezar por eles..."

E quando chega a hora de partir: "Quando a gente entra no carro, a gente se benze. Quem se benze primeiro é o motorista. A gente canta assim:

"Motorista sai de casa, faça a sua devoção,

Pra levar seus romeirinhos a meu Padrinho Cíço Romão.

Ó que passada bendita, é a passada do romeiro,

Que nós vamos visitar a matriz do Juazeiro.

Nossa Senhora das Dores, ela é nossa Mãe boa

Que protege os seus romeiros, romeiros de Alagoas.

Meu Padrinho, me dê licença de atravessar este sertão

Visitar Nossa Senhora, e me dê a salvação".

\section{2: ROMARIA; LITURGIA NAS ESTRADAS.}

Durante a viagem, a criatividade do romeiro é muito expressiva: tudo é habitado por um sentido de solidariedade, de partilha: 
- "Todos têm de sair juntos em romaria e voltar juntos como uma Missa que a gente vai assistir juntos".

- " Quando a gente pára no caminho para fazer a comida, uns vão buscar água, outros lenha, outros as pedras, um romeiro fica em cima do caminhão para dar e receber as bagagens dos outros. Muitas vezes ele fez a promessa de fazer esta penitência na viagem. A gente bota tudo junto, em cima de uma esteira. Depois de comer, a gente não apaga o fogo, mas deixa a lenha que sobrou juntinho das pedras para os outros romeiros que vão chegar depois da gente."

- "Às vezes o caminhão vai por uma estrada errada, ruim... Quando a gente volta para pegar outro caminho, a gente bota um sinal para avisar os outros carros."

- "Às seis horas da noite, a gente reza o Terço à meia-noite, o Ofício de Nossa Senhora"

-"A gente não gosta de chegar em Juazeiro de noite, porque senão a gente encontra a Matriz fechada. Nós achamos melhor dormir mais uma noite no caminho, para chegar às seis horas da manhã, cantando os benditos da chegada."

-"Todos os carros, só saem com a ordem do meu Padrinho e de nossa Mãe. Quando o carro sai de casa, já Padre Cícero e Nossa Senhora das Dores estão esperando no caminho para abrir a estrada para a gente. O Coração de Jesus fica tomando conta da casa até a nossa volta."

-" Durante a Romaria, tudo é de todos, mas a gente não obriga."

- "Já fui oito vezes ao Juazeiro do meu Padim Ciço. É um céu! Pra mim é um céu na terra. Os pobres de Deus tudo junto, homem, mulher, velho, criança... rezando, cantando bendito, se ajudando no caminho, nas barracas durante as esperas, repartindo comida. A gente conta história uns pros outros, reparte sofrimento, imagina as melhorias, sonha acordado. É muito desafogo no meio desta vida sofrida pra nós. E é tanta fé! Fé n'Aquele que pode tudo, nosso Deus. Cada vez que eu vou lá, eu pego um reforço pra lutar na pobreza de pobre. O Céu pra 
mim é uma romaria sem fim, é a pobreza decente no festejo da certeza de que Deus caminha com a gente. ${ }^{21}$

Os Romeiros enfeitam seu meio de transporte de maneira criativa e original: Faixas, flores, bandeirolas, frases bíblicas, imagens de santos, pequenos andores, transformam o veículo em "objeto litúrgico e religioso". Quando chegam a Juazeiro, eles entram cantando, em procissão, com o pequeno andor, pela porta principal da Basílica. Os "santos", que fizeram a viagem, entram também para "visitar" Nossa Senhora. Assim, a cada ano, a comunidade de Nossa Senhora dos Prazeres, padroeira de Maceió, faz a sua visita alegre à casa da Mãe das Dores! Os andores são guardados numa capela durante a romaria, suas saídas são previstas quando os romeiros daquele grupo organizam uma procissão nas ruas da cidade ou na hora da volta para casa.

Como em outros centros de romaria, vários peregrinos vestem-se de túnicas brancas ou azuis (em honra de Nossa Senhora), de cor marrom (por devoção a São Francisco) ou preta (lembrando a batina do Padre Cícero). São "vestes litúrgicas" que o devoto deposita no altar ou oferece a um pedinte, após ter cumprido a sua promessa.

\section{3: ROMARIA: LITURGIA NA CIDADE-SANTA".}

Entrando em Juazeiro, o romeiro segue o "roteiro da fé": é toda a cidade que é santuário sagrado:

"A primeira visita é pra Matriz de Juazeiro. A gente faz três voltas de caminhão, depois, a gente entra na Igreja pela porta principal, reza os benditos e, depois, cada um reza como quer". Geralmente, alguns romeiros cumprem a promessa de entrar na Igreja de joelhos e são acompanhados pelo grupo num gesto de apoio e solidariedade. A "circumambulação" ao redor da Matriz das Dores, ou na Praça do Santuário de São Francisco é um ritual de preparação para entrar "no meio do Centro". Após longas horas de viagem, o romeiro sente a necessidade de "atrasar sua entrada na Igreja" circulando por três vezes ao redor dela,

\footnotetext{
${ }^{21}$ Esse último testemunho foi citado por SOARES, Sebastião Armando Gameleira, op.cit p.32
} 
como para delimitar o espaço sagrado que ele tanto sonhou visitar. Esse ritual é feito também ao redor do monumento ao Padre Cícero, no Horto, ao redor do seu cajado.

Tocar a imagem, escrever seu nome na estátua, deixar seu marco, uma lembrança, uma foto junto ao santo, depositar objetos ou cartas em cima do túmulo ou da cama do Padre Cícero, acender uma vela etc. são tantos gestos de uma liturgia de aproximação do sagrado, onde o romeiro é sujeito e protagonista. Tocar o Santo ou um objeto que lhe pertenceu é feito com grande respeito e seriedade. É uma maneira de apropriar-se de algo de sua força, de sua santidade, de seu poder.

Importante é também levar para casa objetos, lembranças ou presentinhos de Juazeiro, seja apenas uma pedra ou um pouco desta terra abençoada. Uma fretante contou na reunião dos romeiros, um novo ritual que seus romeiros fazem há alguns anos: "A gente guarda a semente ou um caroço de uma fruta que comemos durante a Romaria para plantar em nossa terra. Meu Padrinho sempre dizia que é preciso plantar muitas árvores no Nordeste para ele não virar deserto! E sabem! Já comemos mangas das árvores que plantamos e que nasceram de caroços que levamos de Juazeiro!"

Depois de termos abordado as romarias de Juazeiro que criam uma "espacialidade sagrada", onde estão imbricadas a figura do romeiro e do "Santo Padre Cícero", queremos concluir este estudo com um pensamento de Braga:22

"Se por um lado uma romaria "consagra" o romeiro, em contrapartida é a fé e a prática romeira que factualmente, tornam sagrado o Juazeiro(...) Não existe "Juazeiro sagrado" sem romeiro; mas também não há romeiro sem "Juazeiro sagrado". Não existe o Santo Padrinho Cícero sem afilhado, assim como não tem o afilhado sem o Padrinho Cícero. Resumindo, eles se alimentam e realimentam um do outro, um no outro.(...) $A$ beleza está nos olhos que vêm. O Sagrado está nos olhos de

22 BRAGA, Antônio Mendes da Costa: Padre Cícero, sociologia de um Padre, antropologia de um Santo. Op. Cit, p.328 
quem crê. Isto porque o sagrado é algo que nasce da fé e da prática de quem acredita e torna algo sagrado."

Será que não é este um dos enfoques da Liturgia?

Irmãs Ana Teresa Guimarães e Annette Dumoulin

Irmã Dra.Ana Terezinha Guimarães é formada em Pedagogia e tem doutorado em Psicologia pela Universidade de Lovaina, Bélgica.

Irmã Dra. Anette Domoulin é doutora em Ciência da Educação, pela Universidade de Lovaina. Ambas trabalham pastoralmente em Juazeiro do Norte, Ceará, desde 1976, desenvolvendo uma profunda ciência a respeito da situação romeira local. 